\title{
EXAMINATION OF MOBILE COMMUNICATION SERVICE PROVIDERS IN LATVIA
}

\author{
Viktorija Malkevica ${ }^{1}$, Anda Zvaigzne ${ }^{2}$, Sandra Murinska ${ }^{3}$ \\ ${ }^{1}$ Mg.soc.sc., LMT Retail \& Logistics, Latvia, e-mail: viktorija.malkevica@inbox.lv \\ 22 Dr.oec. associate professor, leading researcher, Rezekne Academy of Technologies, \\ Rezekne, Latvia, e-mail: Anda.Zvaigzne@rta.lv \\ ${ }^{3}$ Dr.sc.comm., assistant professor, leading researcher, Rezekne Academy of \\ Technologies, Rezekne, Latvia, e-mail: Sandra.Murinska@rta.lv
}

Received: 11 September 2020 / Revised: 1 October 2020/ Accepted: 16 October 2020 /

Published: 30 November 2020

\begin{abstract}
The development of telecommunications plays an essential role in the economy, as it affects the opportunities for communication between economic actors at both the national and global levels. Today mobile communication companies, which provide quality communication and information retrieval opportunities through the variety of their services, technological features and tariff plans, are important telecommunication providers.

The aim of the present research is to examine the leading mobile communication service providers in Latvia by employing the theoretical findings of communication technology and telecommunications.

The research used the following methods: monographic, induction and deduction, graphic, comparison, as well as competitiveness assessment based on the competitiveness index.

The research described the theoretical aspects of telecommunications, examined the leading mobile communication service providers in Latvia, their most important financial performance indicators, services and tariff plans offered as well as assessed their competitiveness.

Examining the mobile tariff plans and the services included therein, it was found that they were quite similar. However, an examination of each offer in more detail revealed that there were many nuances that were important to the client and that should be paid attention to. After assessing the competitiveness of the leading mobile communication providers, it was concluded that Latvijas Mobilas Telefons scored the highest number of points, Bite Latvija was in second place and Tele 2 took third place. An assessment of the key factors of competitiveness for the providers revealed that the company Latvijas Mobilais Telefons needed to improve the positions where its competitors had higher ratings: its discount system, the prices of services and the supply of services.
\end{abstract}

Keywords: communication technologies, information technologies, mobile communications, telecommunications, communication services offered, competitiveness. JEL code: $L 96, L 86$.

\section{Introduction}

Over the last decade, the development of telecommunications has provided economic actors in Latvia (households, companies and the government) with opportunities that were not available to them before. By taking advantage of mobile telecommunications, businesses and other economic actors can ensure fast and efficient communication. 
Domestic companies can provide quality communication with their target audiences as well as offer their products in the global market.

The growth of telecommunications companies occurs rapidly in Latvia; consequently, communication opportunities for economic actors develop and improve constantly. Today mobile communication companies, which provide quality communication and information retrieval opportunities through the variety of their services, technological features and tariff plans, are important telecommunication providers.

The aim of the present research is to examine the leading mobile communication service providers in Latvia by employing the theoretical findings of communication technology and telecommunications.

Specific research tasks:

1. to examine the theoretical findings of communication technology and telecommunications;

2. to examine the leading mobile communication service providers in Latvia, their services offered and their competitiveness.

The following hypothesis was put forward: there are no significant differences between the tariff plans offered by the leading mobile communication service providers in Latvia.

The research used the following methods: monographic, induction and deduction, graphic, comparison, as well as competitiveness assessment based on the competitiveness index.

The research used specialist literature, relevant research papers, other publicly available information and Internet resources.

\section{Theoretical aspects of communication technologies and telecommunications}

In this research we look on telecommunications as a tool for economic and social development around the world, stressing the role of information and communication technologies for development and telecommunications as a part of it.

It is undeniable that information and communication technology (ICT) offers immense opportunities for social change. ICTs such as the Internet, mobile phones and social media are becoming ubiquitous. However, their use for positive social change remains complex and contested, in that it involves a myriad of actors and perspectives, societies and cultures, strategies and policies and ultimately winners and losers (Ala-Uddin, 2019).

Information technology is a relatively new area which offers many potential uses. Due to its novelty, what is often forgotten to ask is what the ultimate purposes its application could actually serve are. That is, what can actually be done with it? The spread of ICT is for no good if people have no 
uses for it which would benefit them substantially. The most important question then becomes, from the capabilities perspective, the following: What can information technology do for our capabilities? It is often stated in social scientific writing that the economy is currently moving in a new direction of becoming an informational economy. Furthermore, this economy is seen as being increasingly global in its scope. It is also envisaged that those economic actors not connected to the information networks of the global economy cannot survive in the long run, due to the increased competition in markets reaching everywhere (Lanki, 2006).

As the first decade of the new millennium drew to a close, it became clear that a major subfield of scholarship, policy and practice, that is, information and communication technologies for development or 'ICT4D', had emerged within and beyond the already broad field of communication, development and social changes. Though the roles of new ICTs in development were discussed in the 1980s and 1990s, the accelerated diffusion of digital technologies around the turn of the century greatly increased the possibilities for global information sharing and accelerated development. The looming millennium coincided with technological innovations and initiatives that inspired reflection and dialogue. Many scholars and activists have critiqued ICT4D for repeating the same modernist mistakes of earlier decades, noting further that ICT4D tends to focus on 'have' and 'have not' countries and global regions, neglecting variance within countries and regions (Steeves, Kwami, 2019).

The technological possibilities offered by new and improved underlying infrastructure support almost unlimited transmission capacity on optical fibre networks. These developments will result in a deeper convergence of mobile and fixed networks (Gijrath, 2017).

ICT4D seeks to examine social changes in developing countries as a result of ICTs. Within the mainstream of ICT4D policy and discourse, development is a re-articulation of modernization achieved through economic growth under globalization. Castells describes it as the availability and use of information and communication technologies are a pre-requisite for economic and social development in our world. They are the functional equivalent of electricity in the industrial era. The United Nations, through its various institutions, actively promotes ICT4D as a tool for economic and social development around the world, particularly in developing countries. It is ideally as a complex process that leads to a better, more socially just world via the engendering of citizen participation and empowerment (Steeves, Kwami, 2019).

Authors view communication for development, therefore ICT4D, not predominantly as a process of marketing and networking in the global economy, but ideally as a complex process that leads to a better, more 
socially just world via the engendering of citizen participation and empowerment. Their stance recognizes the importance of considering multiple factors that may affect outcomes, including the ownership and control of the means of communication and networking; the narratives that dominate media and ICT discourse; social movements and local knowledge production; spirituality and religion as communication; and the embodied experience of communication, requiring attention and physical engagement (Steeves, Kwami, 2019).

Mobile groups are present all over the world, in both developed and emerging countries. The European Union (EU) countries are examples of countries with strong institutions that support economic exchanges under a common industry regulation. Under the legal directives of the EU institutions, the mobile telecommunications industry has achieved a high penetration rate in these countries because of a common technological standard, GSM, in the first stages of mobile communications. This favoured the creation of strong European mobile multinationals, such as Telefonica and Vodafone, that started operating in the EU markets and that are present in emerging countries as well (Domínguez, Garrido, Orco, 2016).

Since computing and communication technologies converged, the potential in both business and social networking applications has increased at an exponential rate, the social applications increasing at a rate unimagined in the early days of networking. The development of social computer networks now affects whole communities, the practice outpacing the development of the theoretical concepts on which they may be based. The adoption of electronic networking by whole communities is often a survival strategy in an environment of economic rationalism and declining population. The form of these networks varies from computer networks or virtual communities in that a network of electronic services is superimposed upon an existing geographic community. The intention is not only to survive but to actually strengthen the community. This is achieved by adopting electronic services and communication methods not only to retain the current population but to increase it by structuring an attractive lifestyle of integrated real and virtual services (Domínguez, Garrido, Orco, 2016).

Researchers have looked at success and failure factors of the regulation sector of electronic communications.

The electronic communications sector is atypical as it is subject to specific technological characteristics that pose recurring significant investment issues. The European Union's (EU) Telecoms Single Market (TSM) regulation is aimed at coordinating spectrum licensing and bringing seamless service provision to end-users, wherever they are and no matter what terminal equipment they use. At the same time, the on-going transition from traditional telecommunications systems to all-IP packet switched data 
grids will challenge the electronic communications networks (ECNs) operators' business models further. The operators must upgrade or replace their existing networks to cater for the implementation of $5 \mathrm{G}$ frequencies (Gijrath, 2017).

Where the EU Commission expressed its keenness on steering towards more convergence between fixed and mobile infrastructure, it must be observed that impact of regulation on fixed ECN operators is rather different from the impact on mobile ECN operators. Fixed ECN operators continue to be subject to stronger regulatory scrutiny than mobile operators. Unlike the case for regulating fixed networks, ex ante market regulation of mobile ECN operators is less likely to occur. This is due to the circumstance that (most) mobile players are not considered to have significant market power (a past exception being the market for mobile terminating tariffs) (Gijrath, 2017).

With the growing ubiquity of mobile communications and rapid innovation in the mobile market, our media landscape is a highly volatile one where consumers have to constantly adapt to mutable platforms and everevolving affordances. At the same time, the increasingly widespread use of smartphones and other locative media is further enriching and complicating mobile media (Lim, 2013).

Next, the research described and examined the leading mobile communication service providers in Latvia, their services and tariff plans offered, and assessed their competitiveness. The leading mobile communication service providers were identified based on the data provided by the Annual Report on Business in Latvia that has ranked the leading companies in the industry (Annual Report on Business in Latvia, 2019)

\section{Leading mobile communication service providers in Latvia: the services, tariff plans and competitiveness}

Latvijas Mobilais Telefons (LMT) is the largest mobile operator in Latvia in terms of number of clients, turnover and network coverage that also has the widest customer service network. As a market leader in innovation, LMT offers its clients a full range of high-quality telecommunication services: voice communication, an unlimited high-speed mobile Internet, as well as mobile television, smart television and other services. LMT is the leading provider of mobile communications services in Latvia and an essential component of the social and economic infrastructures of Latvia. At the same time, LMT is a direct competitor for Bite Latvija and Tele 2 that significantly affect the company's operations and goals and make it communicate more actively with clients and create innovative ideas for enhancing its competitiveness. The turnovers of the largest mobile communications companies LMT, Tele 2 and Bite Latvija are shown in Table 1. 
Table 1. Turnovers of the leading mobile communication service providers in 2018 and 2019 (mln. EUR) (authors' compilation based on Crediweb financial reports (LMT, Tele 2, Bite Latvija)

\begin{tabular}{|l|c|c|c|}
\hline \multicolumn{1}{|c|}{ Company } & $\begin{array}{c}\text { Turnover in 2018 } \\
\text { (mln. EUR) }\end{array}$ & $\begin{array}{c}\text { Turnover in 2019 } \\
\text { (mln. EUR) }\end{array}$ & $\begin{array}{c}\text { Change in turnover from } \\
\text { previous year (mln. EUR) }\end{array}$ \\
\hline $\begin{array}{l}\text { Latvija Mobilais } \\
\text { Telefons }\end{array}$ & 216 & 230 & +14 \\
\hline Tele 2 & 125.8 & 130.5 & +4.7 \\
\hline Bite Latvija & 92.9 & 106.3 & +13.4 \\
\hline
\end{tabular}

As shown in Table 1, the leader in the mobile communications market in terms of turnover and profit was LMT, yet in the period 2018-2019, Bite Latvija made a significant profit of EUR $13 \mathrm{mln}$. (Crediweb annual report, 2019). This indicator allows us to conclude that Bite Latvija increasingly invested in its network and development, which contributed to the client choice and growth of the company.

The mobile communication service providers provide a variety of services, starting with the purchase of smartphones, computers, smart assistants and small household appliances through to voice communication and Internet connection. Table 2 summarizes the tariff plans of the providers for voice communication.

Table 2. Comparison of the tariff plans of the leading mobile communication service providers (authors' compilation based on publicly available data from the websites of Bite Latvija, Tele 2 and LMT)

\begin{tabular}{|c|c|c|c|c|c|}
\hline Tariff plan & $\begin{array}{c}\text { Price } \\
\text { (EUR/month) }\end{array}$ & $\begin{array}{l}\text { Min/SMS } \\
\text { included }\end{array}$ & $\begin{array}{c}\text { MB } \\
\text { included }\end{array}$ & $\begin{array}{l}\text { Calls to } \\
\text { Europe }\end{array}$ & $\begin{array}{c}\text { Internet } \\
\text { in Europe }\end{array}$ \\
\hline \multicolumn{6}{|c|}{ Bite LATVIJA } \\
\hline Bite Starts & 2.00 & $\begin{array}{l}30 \mathrm{~min} \\
30 \mathrm{SMS}\end{array}$ & - & $30 \min$ & $\begin{array}{c}0.10 \\
\text { EUR/MB }\end{array}$ \\
\hline Bite $500 \mathrm{Mb}$ & 8.50 & $\begin{array}{l}\infty \text { calls } \\
\infty \text { SMS }\end{array}$ & 500 & $50 \mathrm{~min}$ & $500 \mathrm{MB}$ \\
\hline Bite 2GB & 11.50 & $\begin{array}{l}\infty \text { calls } \\
\infty \text { SMS }\end{array}$ & $2 \mathrm{~GB}$ & $100 \mathrm{~min}$ & $2 \mathrm{~GB}$ \\
\hline Bite 5GB & 14.50 & $\begin{array}{l}\infty \text { calls } \\
\infty \text { SMS }\end{array}$ & $5 \mathrm{~GB}$ & $100 \mathrm{~min}$ & $5 \mathrm{~GB}$ \\
\hline Bite 10GB & 18.50 & $\begin{array}{l}\infty \text { calls } \\
\infty \text { SMS }\end{array}$ & $10 \mathrm{~GB}$ & $200 \mathrm{~min}$ & $9 \mathrm{~GB}$ \\
\hline Bite Unlimited & 22.50 & $\begin{array}{l}\infty \text { calls } \\
\infty \text { SMS }\end{array}$ & $\infty$ & $500 \mathrm{~min}$ & $11 \mathrm{~GB}$ \\
\hline $\begin{array}{l}\text { Bite Youth } \\
\text { (aged 6-20 years) }\end{array}$ & 9.90 & $\begin{array}{l}\infty \text { calls } \\
\infty \text { SMS }\end{array}$ & $\infty$ & $\infty$ & $5 \mathrm{~GB}$ \\
\hline $\begin{array}{l}\text { Bite Schoolchildren } \\
\text { (aged 6-17 years) }\end{array}$ & 5.50 & $\begin{array}{l}120 \text { min } \\
120 \text { SMS }\end{array}$ & $1 \mathrm{~GB}$ & $120 \mathrm{~min}$ & $1 \mathrm{~GB}$ \\
\hline \multicolumn{6}{|c|}{ Tele 2} \\
\hline $1.5 \mathrm{~GB}$ & 10.99 & & $1.5 \mathrm{~GB}$ & $\infty$ & $1.5 \mathrm{~GB}$ \\
\hline
\end{tabular}




\begin{tabular}{|c|c|c|c|c|c|}
\hline Tariff plan & $\begin{array}{c}\text { Price } \\
\text { (EUR/month) }\end{array}$ & $\begin{array}{l}\text { Min/SMS } \\
\text { included }\end{array}$ & $\begin{array}{c}\text { MB } \\
\text { included }\end{array}$ & $\begin{array}{l}\text { Calls to } \\
\text { Europe }\end{array}$ & $\begin{array}{r}\text { Internet } \\
\text { in Europe }\end{array}$ \\
\hline $5 \mathrm{~GB}$ & 14.99 & \multirow{7}{*}{$\begin{array}{l}\infty \text { calls } \\
\infty \text { SMS }\end{array}$} & $5 \mathrm{~GB}$ & & $5 \mathrm{~GB}$ \\
\hline $15 \mathrm{~GB}$ & 19.99 & & $15 \mathrm{~GB}$ & & $8 \mathrm{~GB}$ \\
\hline Unlimited & 22.99 & & $\infty$ & & $9 \mathrm{~GB}$ \\
\hline Unlimited for Youth & 15.90 & & $\infty$ & & $6 \mathrm{~GB}$ \\
\hline 10 GB for Family & 14.99 & & $10 \mathrm{~GB}$ & & $5 \mathrm{~GB}$ \\
\hline $\begin{array}{ll}\text { Unlimited for } & \text { fchoolchildren } \\
\text { (aged 6-17 years) } & \end{array}$ & 9.90 & & $\infty$ & & $4 \mathrm{~GB}$ \\
\hline 2 GB for Seniors & 8.90 & & $2 \mathrm{~GB}$ & & $2 \mathrm{~GB}$ \\
\hline Charge per unit & 9.49 & $\begin{array}{c}0.11 \\
\text { EUR/min } \\
0.06 \\
\text { EUR/SMS }\end{array}$ & $\begin{array}{c}0.41 \\
\text { EUR/Mb }\end{array}$ & $\begin{array}{c}0.11 \\
\text { EUR/min }\end{array}$ & $\begin{array}{c}0.41 \\
\text { EUR/MB }\end{array}$ \\
\hline \multicolumn{6}{|c|}{ Latvijas Mobilais Telefons } \\
\hline Freedom & 12.90 & \multirow{5}{*}{$\begin{array}{l}\infty \text { calls } \\
\infty \text { SMS }\end{array}$} & - & \multirow{5}{*}{$\infty$} & - \\
\hline $\begin{array}{l}\text { Schoolchildren } \\
\text { (aged 6-17 years) }\end{array}$ & 9.96 & & $\infty$ & & $5.5 \mathrm{~GB}$ \\
\hline Youth & 15.97 & & $\infty$ & & $5.5 \mathrm{~GB}$ \\
\hline Seniors + & 9.50 & & $2 \mathrm{~GB}$ & & $2 \mathrm{~GB}$ \\
\hline Freedom in Europe VIP & 60.00 & & $\infty$ & & $27.67 \mathrm{~GB}$ \\
\hline MINI & 2.00 & $\begin{array}{c}0.12 \\
\text { EUR/min } \\
0.07 \\
\text { EUR/SMS }\end{array}$ & - & $\begin{array}{l}0.12 \text { EUR/ } \\
\min (\text { EEZ) }\end{array}$ & - \\
\hline \multicolumn{6}{|l|}{$\begin{array}{l}\begin{array}{l}\text { Internet on the } \\
\text { phone }\end{array} \\
\end{array}$} \\
\hline Independence & 11.99 & - & $\infty$ & - & $5.5 \mathrm{~GB}$ \\
\hline $1 \mathrm{~GB}$ & 3.99 & - & $1 \mathrm{~GB}$ & - & $1 \mathrm{~GB}$ \\
\hline $3 \mathrm{~GB}$ & 7.99 & - & $3 \mathrm{~GB}$ & - & $3 \mathrm{~GB}$ \\
\hline
\end{tabular}

Examining the mobile tariff plans and the services included therein, it was found that they were quite similar. However, an examination of each offer in more detail revealed that there were many nuances that were important to the client and that should be paid attention to when making a choice of an operator.

Summarising the tariff plans of the operator Bite Latvija and analysing the available information, the following service nuances were identified (BITE Latvija website, 2020):

- unlimited communication only to four networks in Latvia: Bite Latvija, LMT, Tele 2 and TET;

- the tariff plan Bite Starts, after 30 min being used up and 30 SMS sent (both in Latvia and 30 European countries), applies a fee of $0.10 \mathrm{EUR} / \mathrm{min}$ for calls within Latvia and to the European Economic Area (EEA) and a fee of EUR 0.07 for SMS;

- all the tariff plans apply a fee of EUR 0.07 on SMS sent to the EEA; 
- the client receives information about paid calls to other operators' numbers in the form of a text message during the call;

- there is a limited number of free minutes for international calls from Latvia to EEA countries; beyond the free minutes, the fee is 0.23 EUR/min (e.g. 10 minutes cost EUR 2.30);

- under the tariff plan Bite Starts, Internet usage costs 0.10 EUR/MB both in Latvia and the EEA;

- in Latvia and the EEA, the tariff plans apply certain surcharges on data usage beyond the free limit (with an increment of $1 \mathrm{~Kb}$ ):

○ Bite $500 \mathrm{Mb}-200 \mathrm{MB} / 2.50 \mathrm{EUR}$;

○ Bite $2 \mathrm{~GB}-500 \mathrm{MB} / 2.50 \mathrm{EUR}$;

○ Bite $5 \mathrm{~GB}-1 \mathrm{~GB} / 2.50$ EUR;

o Bite $10 \mathrm{~GB}$ - each next GB in Latvia - EUR 2.50, each next MB in Europe - 0.0052 EUR;

○ Bite Unlimited - each next MB in Europe - 0.0052 EUR (Bite Latvija website, 2020)

- For new clients, the fees and data are calculated as a proportion of the number of days;

- TOP applications (Facebook, Twitter, Waze, WhatsApp, draugiem.lv, Delfi) are available for free only for three months or unlimitedly (Bite Unlimited and Bite Schoolchildren);

- unlimited use of the TOP applications beyond three months is charged at 2 EUR/month.

- free data are available only in Latvia; free use of the TOP applications abroad is limited to the amount of data included in the tariff plans.

- For Tele 2, the following service nuances were identified:

- unlimited free communication within Latvia is not available to all phone numbers, for example, a call to Alviksa Taxi costs $0.25 \mathrm{EUR} / \mathrm{min}$, while a call to the Family Doctor Advice Phone is charged $0.14 \mathrm{EUR} / \mathrm{min}$;

- the tariff plans $1.5 \mathrm{~GB}$ and $5 \mathrm{~GB}$ provide paid international calls, including those to EEA countries;

- the tariff plans $1.5 \mathrm{~GB}$ and $5 \mathrm{~GB}$ provide SMS messaging from Latvia to the EEA at a fee of 0.07 EUR/SMS.

- beyond the limits set by the tariff plans for Latvia and the EEA, the following surcharges apply (Bite Latvija website, 2020).

○ $1.5 \mathrm{~GB}-500 \mathrm{MB} / 2.99 \mathrm{EUR}$;

○ $5 \mathrm{~GB}-500 \mathrm{MB} / 2.99 \mathrm{EUR}$;

- $15 \mathrm{~GB}-1 \mathrm{~GB} / 3.99 \mathrm{EUR}$;

○ Unlimited - 0.0053 EUR/Mb (EEA).

After summarizing the information obtained, it could be concluded that in relation to the tariff plans offered by BITE Latvija and TELE 2, the client 
must pay more attention to and obtain as much information as possible about what really is included in the service provided in order not to receive bills with an unexpected expense. In addition to their tariff plans, the companies Bite Latvija and Tele 2 provide various bonuses. For example, Bite Latvija provides phone screen insurance for one month, a free antivirus application for three months and unlimited Internet usage for applications for three months. For its clients, Tele 2, however, additionally offers 30 day-free TV and tablet SIM cards with free 1-4 GB data, depending on the tariff plan. On the one hand, the bonuses offered by BITE Latvija and Tele 2 are a good way to attract new clients because any client is given an impression that $\mathrm{s} / \mathrm{he}$, using the same services, receives much more from the mentioned operators than from another mobile operator. However, on the other hand, it is rarely explained to the customer that the bonuses to be provided are for a limited period and must later be switched off permanently if they do not wish to use them in order not to pay an additional subscription fee. This small service nuance could also lead to conflict with the customer and a loss of his/her trust.

After summarizing the tariff plans offered, it could also be concluded that the range of services is broad, and each client is able to find the most suitable option. Clients often choose a service provider according to their needs - the environment, coverage and price. At the same time, client choices are affected by many other factors such as advertising campaigns, discounts, friend/acquaintance recommendations or company prestige, which encourage the customer to make an emotional choice in favour of a service provider without fully considering all the advantages and disadvantages. The research performed an assessment of the companies LMT, Bite Latvija and Tele 2, calculating a competitiveness index for the companies, and the results are presented in Table 3.

\section{Table 3. Ratings of the performance of mobile communication service providers and the competitiveness index for the providers}

(authors' calculations)

\begin{tabular}{|l|c|c|c|c|c|c|c|}
\hline \multirow{2}{*}{$\begin{array}{l}\text { Key factors of } \\
\text { competitiveness }\end{array}$} & \multirow{2}{*}{ Weight } & \multicolumn{2}{|c|}{$\begin{array}{c}\text { Latvijas Mobilais } \\
\text { Telefons }\end{array}$} & \multicolumn{2}{c|}{ Bite Latvija } & \multicolumn{2}{c|}{ Tele 2 } \\
\cline { 2 - 8 } & & Rating & $\mathbf{4 = 2 * 3}$ & Rating & $\mathbf{6 = 2 * 5}$ & Rating & 8=2*7 \\
\hline Quality & 0.1 & 8 & 0.8 & 6 & 0.6 & 6 & 0.6 \\
\hline Price of & 0.1 & 6 & 0.6 & 7 & 0.7 & 6 & 0.6 \\
\hline $\begin{array}{l}\text { Supply } \\
\text { products/assortme } \\
\text { nt }\end{array}$ & 0.05 & 7 & 0.35 & 7 & 0.35 & 7 & 0.35 \\
\hline Working hours & 0.1 & 8 & 0.8 & 8 & 0.8 & 8 & 0.8 \\
\hline Service & 0.1 & 9 & 0.9 & 7 & 0.7 & 6 & 0.6 \\
\hline Company image & 0.1 & 9 & 0.9 & 7 & 0.7 & 6 & 0.6 \\
\hline Discount system & 0.05 & 6 & 0.3 & 7 & 0.35 & 7 & 0.35 \\
\hline
\end{tabular}




\begin{tabular}{|c|c|c|c|c|c|c|c|}
\hline $\begin{array}{l}\text { Advertisement } \\
\text { campaign }\end{array}$ & 0.07 & 7 & 0.49 & 7 & 0.49 & 7 & 0.49 \\
\hline $\begin{array}{l}\text { Company } \\
\text { development }\end{array}$ & 0.03 & 9 & 0.27 & 8 & 0.24 & 8 & 0.24 \\
\hline $\begin{array}{l}\text { Professional } \\
\text { personnel }\end{array}$ & 0.1 & 8 & 0.8 & 8 & 0.8 & 7 & 0.7 \\
\hline Experience & 0.03 & 8 & 0.24 & 6 & 0.18 & 7 & 0.21 \\
\hline $\begin{array}{ll}\text { Application } & \text { of } \\
\text { modern } & \\
\text { technologies } & \\
\end{array}$ & 0.07 & 8 & 0.56 & 8 & 0.56 & 8 & 0.56 \\
\hline $\begin{array}{l}\text { Wide range of } \\
\text { services }\end{array}$ & 0.04 & 7 & 0.28 & 8 & 0.32 & 8 & 0.32 \\
\hline Financial stability & 0.06 & 8 & 0.48 & 7 & 0.42 & 7 & 0.24 \\
\hline Total: & 1.0 & 108 & 7.77 & 101 & 7.21 & 98 & 6.66 \\
\hline
\end{tabular}

As shown in Table 3, LMT scored the highest number of points (7.7), Bite Latvija was in second place (7.21) and Tele 2 took third place (6.66). An assessment of the key factors of competitiveness for the providers revealed that LMT needed to improve the positions where its competitors had higher ratings: its discount system, the prices of services and the supply of services. In addition, as shown in Table 3, a comparison of the tariff plans revealed that LMT offered relatively fewer options than Tele 2 and Bite Latvija did, as well as LMT's offers (tariff plans) were inflexible, which might make it difficult for the customer to make a choice. At the same time, high and inflexible service prices were an opportunity for the competitors to offer lower service costs and attract new clients.

Additional factors affecting competition are as follows:

1. progress in broadband wireless technology (higher-speed and quality data transmission services);

2. development of communication devices (new higher value-added services are supplied);

3. users tend to use multiple devices having a mobile connection.

The content of information available on the Internet has changed significantly in recent years owing to technological progress. In case the user needs some information, the fastest, cheapest and most convenient way to search for information is the Internet; it is available both on a computer and a smartphone, where it could be conveniently surfed at no extra fee and, if necessary, repeatedly. The Internet is also used to receive TV services.

Broadband wireless technology has developed rapidly. Mobile broadband technology, also called wireless wide area network (WWAN) technology, provides high-speed wireless Internet access via portable devices. This type of Internet provides higher data transfer speeds than a normal Internet connection does and allows combining the transmission of different data simultaneously (Competition Council, 2015). 
According to the data from the Public Utilities Commission (Public Utilities Commission, 2019), it could be concluded that all the national mobile operators provide high-quality and stable Internet coverage to their clients, and their performance tend to increase. In terms of average download data, the best Internet was provided by Tele 2, LMT was in second place and Bite Latvia was in third place.

The assessment of the companies allows us to conclude that LMT was the leader in the mobile communications market of Latvia, while Bite Latvija and Tele 2 strongly competed for new clients and the position of the leading mobile operator. This means that LMT should constantly make new offers to clients, which provide added value to the company and its clients as well as contribute to their client loyalty.

The supply of services and reliable technological solutions are the basis for the stability and growth of LMT's client base; in 2017 compared with 2016 , the number of connections increased by $3 \%$. The number of connections used to provide various smart solutions grew particularly fast, at a rate of $18 \%$ a year. New opportunities to use unlimited Internet were created for the users of prepaid services; this kind of progress facilitated the availability of the Internet also to prepaid users (Sustainability Report, 2017).

LMT has developed the household segment by offering innovative solutions to the households. For example, since 2017, the Internet service for home has been offered with no speed limits. For several years, LMT has developed the category of smart assistants to make everyday life easier, and since 2017 LMT also offers smart television for home, which is a conceptually new service - the television becomes a leisure centre where the clients can not only watch the usual TV channels but also use the content library, download applications etc. By providing smart television for home on the mobile network, LMT makes the television available in less accessible regions.

LMT has established an e-shop, which is easily accessible and browsable from mobile devices. Since 2017, LMT e-shop offers little-used equipment, which facilitates the integration of used equipment into the market. In 2017 too, the demand for data services on the LMT network continued increasing, and the number of users of the service "Internet on the phone" increased by $19 \%$ during the year. This result was achieved by providing the most suitable solution for clients. This allows various groups of the population to take advantage of the digital ecosystem more effectively and ensures their involvement in social processes as well as reduces social exclusion. According to research studies, LMT was the second largest Internet provider in Latvia. LMT offers its clients not only the Internet on the phone but also a high-quality Internet service for home/office. Both unlimited calls and 
Internet access in Europe increased the mobility of citizens in Europe in 2017 - no more worrying about communication during business or leisure trips. The technological capabilities of LMT are not limited to a successful voice connection or a high Internet speed - LMT has successfully developed to provide new services to business clients (Sustainability Report, 2016).

\section{Conclusions and suggestions}

1. Today mobile communication companies, which provide quality communication and information retrieval opportunities through the variety of their services, technological features and tariff plans, are important telecommunication providers.

2. LMT was the leader in the mobile communications market of Latvia, while Bite Latvija and Tele 2 strongly competed for new clients and the position of the leading mobile operator. LMT should constantly make new offers to clients, which provide added value to the company and its clients as well as contribute to their client loyalty.

3. Examining the mobile tariff plans and the services included therein, it was found that they were quite similar. Accordingly, the hypothesis proved to be true. However, an examination of each offer in more detail revealed that there were many nuances that were important to the client and that should be paid attention to when making a choice of an operator.

4. LMT, Bite Latvija and TELE 2 should continue developing and introducing innovations and modernizing their infrastructures by enhancing the IT solutions implemented, such as $5 \mathrm{G}$ technologies, and modernizing their current technologies.

5. The Marketing Department of Latvijas Mobilais Telefons is recommended to consider a possibility of introducing flexible discount systems for its tariff plans, facilitate the creation of new services that are attractive to clients and promote communication through advertising campaigns.

6. LMT, Bite Latvija and Tele 2 should envisage adequate investments in the enhancement of their network infrastructures and the quality of services in the event of a considerable increase in the number of clients or network congestion in order to ensure their stable operation.

\section{References}

1. Ala-Uddin, M. (2019). Books Review. Asia Pacific Media Educator, 29 (2), 279-290

2. Bite Latvija website. (2020). Retrieved from www.bite.lv

3. Crediweb. (2019). SIA „Bite Latvija” finanšu pārskats. Retrieved from https://www.crediweb.lv/BITE-LATVIJA/40003742426/ 
4. Crediweb. (2019). SIA „Latvijas Mobilais telefons, finanšu pārskats. Retrieved from https://www.crediweb.lv/LATVIJAS-MOBILAIS-TELEFONS/50003050931

5. Crediweb. (2019). SIA „Tele 2, finanšu pārskats. Retrieved from https://www.crediweb.lv/TELE2/40003272854/

6. Domínguez, B., Garrido, E., Orco, R. (2016). Multimarket contact and performance: Evidence from emerging economies. BRQ Business Research Quarterly, 19, 278-288.

7. Gijrath, S. (2017). Telecommunications networks: Towards smarter regulation and contracts? Competition and Regulation in Network Industries, 18 (3-4), 175-197.

8. Ilgtspējas pārskats. (2016). Latvijas Mobilais telefons. Retrieved from https://static.lmt.lv/lmt/files/lmt_ilgtspejas-parskats_2016.pdf

9. Ilgtspējas pārskats (2017). Latvijas Mobilais telefons. Retrieved from https://lmt.mstatic.lv/lmt/files/parskati/lmt_ilgtspejas_parskats_2017.pdf

10. Konkurences padome (2015). Mobilo sakaru mazumtirdzniecības pakalpojumu tarifu uzraudzība Retrieved from https://www.kp.gov.lv/oldfiles/38/citi\%2Fmobilo_sakaru_uzraudziba.pdf

11. Lanki, J. (2006). Why Would Information and Communications Technology Contribute to Development at All? An Ethical Inquiry into the Possibilities of ICT in Development. E-Learning and Digital Media, 3 (3), 448-461.

12. Latvijas biznesa gada pärskats 2019 (2019). Retrieved from firmas.lv https://www.firmas.lv/lbgpp/2019/raksti/telekomunikacijas

13. Lim, S. (2013). On mobile communication and youth "deviance": Beyond moral, media and mobile panics. Mobile Media \& Communication, 1 (1), 96-101.

14. LMT website. (2020). Retrieved from www.lmt.lv

15. Sabiedrisko pakalpojumu regulēšanas komisija (2019). Elektronisko sakaru pakalpojumu kvalitātes pārskats par 2019. gadu. Retrieved from https://www.sprk.gov.lv/sites/default/files/editor/ESPD/Faili/Parskati/KVALIT ATESPARSKATS2019.pdf

16. Steeves, L., Kwami, J. (2019). Social Context in Development Communication: Reflecting on Gender and Information and Communication Technologies for Development in Ghana. Asia Pacific Media Educator, 29 (2), 106-122

17. Tele2 website. (2020). Retrieved from www.tele2.lv 